Anim. Reprod., v.13, n.3, p.346-354, Jul./Sept. 2016

\title{
Embryo maternal immune interactions in cattle
}

\author{
T. Fair ${ }^{1}$ \\ School of Agriculture and Food Sciences, University College Dublin, Ireland.
}

\begin{abstract}
Mammalian embryo implantation requires the priming of the maternal immune system, but, not the provocation. There are many examples of conditions where a disturbed or aberrant immune profile during embryo implantation leads to pregnancy loss. However, these studies are primarily associated with human and mouse species; data is generally limited for cattle and livestock. Most available information centres on the endometrial response to interferon tau (IFNT), a type I antiviral cytokine, which is the maternal recognition factor for cattle and sheep. Interferon tau secretion by the embryo and detection by the dam is critical to corpus luteum (CL) maintenance and pregnancy retention. However, the large volume of bovine endometrial and conceptual transcriptomic data highlights a broader more integral role of the maternal immune system in the establishment of pregnancy in cattle. When taken together with available immunohistochemistry and flow cytometry data from livestock, mouse, and human, a profile of immune cell involvement from ovulation to conception and placentation emerges. The key events of pregnancy establishment in cattle and the involvement of the maternal immune system will be discussed.
\end{abstract}

Keywords: Cow implantation pregnancy immunesystem embryo.

\section{Introduction}

The maternal immune system plays a critical role in mammalian embryo implantation. Successful establishment of pregnancy requires the activation of a controlled immune response that is simultaneously responsive and tolerant towards paternal antigens and the semi-allogenic embryo. The discipline of Reproductive Immunology has received considerable attention from a human clinical point of view and much data has been gathered from patients and generated from various mouse and in vitro model systems. In contrast, information from cattle mostly revolves around the endometrial response to the maternal recognition factor for cattle and sheep, the type I antiviral cytokine, interferon tau (IFNT), detection of which by the dam is critical to corpus luteum (CL) maintenance and the establishment of pregnancy. The greatest source of information has come from the large volume of bovine endometrial and conceptal transcriptomic data that has been generated in the past decade. The emerging knowledge clearly indicates that regardless of specificities in placentation physiology, an appropriate maternal immune response is just as critical to the establishment of pregnancy in cattle as it is in human and rodents.

In cattle, the first three to four cell cycle divisions post fertilization occur in the oviduct, such that the embryo enters the uterus on approximately day 4 post fertilization. There it undergoes a number of cell divisions to form the morula which, after differentiation, forms a blastocyst consisting of the inner cells mass (which will eventually give rise to the embryo/foetus) and an outer cell mass consisting of trophectoderm cells which ultimately give rise to the placenta. Up to this stage, the embryo is encased in the glycoprotein shell, the zona pellucida. Therefore the endometrial lining is not exposed to paternal antigens again until hatching, which occurs from day 8 to 9 post fertilization. Transcriptomic analysis of the bovine endometrium during this early stage of pregnancy indicates little or no change in gene expression in response to the zonaenclosed blastocyst stage embryo (Forde et al., 2011; Forde and Lonergan, 2012). Once hatched, the blastocyst forms an ovoid-shaped conceptus between days 12-14 and the elongation process begins. Elongation entails rapid proliferation of the conceptus trophectoderm cells, reaching 3-4 mm or more in length by day 14 (Randi et al., 2015), and $25 \mathrm{~cm}$ or more in length by day 17 . As the embryo elongates, the trophectoderm and endometrial luminal epithelium (LE) become closely apposed, see Spencer et al. (2007), for review. During this period the conceptus relies on maternal secretions, collectively termed histotroph, for survival (Bazer, 1975). In contrast to mouse and human species, implantation in cattle is non-invasive. It is characterized by a superficial attachment and adhesion of the trophectoderm to caruncular and intercaruncular areas, commencing about day 19 (see Brooks et al., 2014), for review. During implantation, bovine trophectoderm cells form binucleate cells (BNCs) as well as trinucleate cells (TNCs), TNCs are products of fusion between binucleate cells and uterine epithelial cells (Wooding and Beckers, 1987) and are only located in the endometrium (Wooding, 1992). These multinuclear cells may play a role in implantation, contributing to the adhesion between conceptus and uterine endometrium at the placentomes. In cattle, several integrin family members (ITGs) have been characterized at the uteroplacental interface during trophectoderm attachment (MacIntyre et al., 2002; Pfarrer et al., 2003) and placentation (Pfarrer, 2006) periods and are believed to play constitutive roles. Similarly, the transmembrane glycoprotein, vascular cell adhesion -molecule (Osborn et al., 1989), is also regarded as a cell adhesion mediator during the processes of lymphocyte homing (May et al., 1993), angiogenesis 
(Ding et al., 2003) and allantoic membrane fusion to the chorion (Gurtner et al., 1995). The key events and interactions between the embryo and the dam are presented and reviewed.

\section{The role of the embryo in the maternal immune response}

\section{Response to insemination}

During transmission of seminal plasma (SP) at coitus, cells of the maternal immune system recognize various signaling constituents of semen, including interleukin (IL) -8, transforming growth factor beta (TGFB) and IFNG. In addition, sperm antigens are recognized as foreign (Robertson, 2005). The recognition of non-self initiates activation of a maternal immune response, which may ultimately confer immunological tolerance to paternal antigens that will be expressed by the embryo that develops after fertilization (Moldenhauer et al., 2009). The first stage of the maternal immune response is characterized by an influx of eosinophils and neutrophils to the uterine lumen. Data from mice show that chemoattractants released by these cells, such as granulocyte macrophage colony-stimulating factor (GM-CSF) and (IL) -6, attract both monocytes and dendritic cells, potentially creating an environment that regulates the inflammatory status of responding macrophages and increases expression of factors which promote early embryo development (Robertson et al., 1996, 2000; Robertson, 2007; Bromfield et al., 2014). Data from mice indicate that the absence of changes in the reproductive tract caused by SP can alter the developmental program of the developing conceptus (Bromfield, 2014). This cell-free, fluid fraction of the ejaculate is significantly diluted during semen preparation for use in AI programs, thus cows bred in this manner are only exposed to trace amount of SP. However, the relatively high pregnancy rates achieved in cattle following artificial insemination (AI) or embryo transfer (ET) suggest that maternal exposure to SP is not a critical component of the maternal immune response in cattle (Lima et al., 2009; Odhiambo et al., 2009).

Molecular response of maternal endometrium to the embryo

The presence of a rapidly elongating embryo is certainly registered by the maternal endometrium, as there is a dramatic change in global gene expression at this time (Forde et al., 2011). The type 1 interferon, interferon tau (IFNT), is the main signaling factor in maternal detection/recognition of pregnancy in cattle and sheep (Hansen et al., 1999; Choi et al., 2003). IFNT is secreted by the elongating conceptus, specifically the trophectoderm (Robinson et al., 2006). It is believed that the luminal epithelium of the uterine endometrium is the primary target for IFNT (Roberts et al., 1992; Imakawa et al., 2002); IFNT binds to a common receptor complex with two polypeptide subunits (IFNAR1 and IFNAR2; Rosenfeld et al., 2002). There is evidence to suggest that IFNT can reach the stroma, the uterine myometrium (Ott et al., 1998, Johnson et al., 1999, Hicks et al., 2003) and most likely, the circulating immune cells and the ovaries as well (Shirasuna et al., 2012). IFNT acts on the endometrium to stimulate the expression of genes that promote conceptus growth and development and induce uterine receptivity (Hansen et al., 1997, Johnson et al., 2000, Song et al., 2007; Mansouri-Attia et al., 2012). Candidate and global gene expression analysis revealed that a classical Type I IFN response during the peri-implantation period is induced by the conceptus/IFNT (Li and Roberts, 1994; Spencer et al., 2008; Mansouri-Attia et al., 2012;). Induced endometrial classical Type I IFN stimulated genes (ISGs) include, 2',5' -oligoadenylate synthetase 1, OAS1 or ISG15, MCP1 Chemokine (C-X-C motif) ligand 5; CXCL5, (for review, see Forde and Lonergan, (2012). The expression of several chemokines is induced in endometrial tissues including chemokine ligands 10 (CXCL10) and 9 (CXCL9); (Nagaoka et al., 2003b, Imakawa et al., 2006). Endometrial CXCL10 attracts immune cells to the caruncular regions of the endometrium (Nagaoka et al., 2003a), and by acting through the CXCL10 receptor, CXCR3, this chemokine regulates $\mathrm{TE}$ cell migration and integrin expression (Imakawa et al., 2006).

Conceptus-maternal communication is vital for the successful establishment and maintenance of pregnancy, Sub-optimal communication, resulting from impairment of conceptus development and/or from abnormal uterine receptivity, contributes to a high incidence of embryonic mortality (see Lonergan and Forde, 2014, for review). Using RNA sequencing, Mamo et al. (2011) described the temporal changes in transcriptional profiles of the bovine conceptus from a spherical blastocyst on day 7 through days 10, 13, 16 and 19 , corresponding to the formation of an ovoid conceptus, initiation of elongation, maternal recognition of pregnancy to a filamentous conceptus at the initiation of implantation on day 19. Generally, genes encoding trophoblast kunitz domain proteins, pregnancyassociated glycoproteins, cytoskeletal transcripts, heat shock proteins and calcium-binding proteins had highest expression levels at each of these stages of development (Lonergan and Forde, 2014; Mamo et al., 2011). Bauersachs et al. (2012) carried out a gene set enrichment analysis of several global transcriptomic datasets from days 15, 16, 17, 18 and 20 of the oestrus cycle or pregnancy and identified a conceptus-induced signature in the endometrium during the process of pregnancy recognition. Together with progesterone (P4), IFNT regulates endometrial gene expression necessary for the establishment of the proper uterine environment during the implantation period (Klein et al., 2006). A panel of approximately 30 genes was identified as expressed on day 16 as part of the early endometrial response to the conceptus and may represent early endometrial markers of a viable preimplantation conceptus (Bauersachs et al., 2006, Mansouri-Attia et al., 2009a), reviewed by Lonergan and Forde (Forde and Lonergan, 2012). Although most data demonstrates that the main molecule affecting the 
endometrium is IFNT, additional conceptus secreted molecules, including prostaglandins (PG; Dorniak et al., 2012, Spencer et al., 2013) and cortisol (Dorniak et al., 2013 b), also act on the endometrium. An additional, but critically important action of IFNT, is the attenuation of endometrial PGF2a secretion, to maintain luteal production of P4. IFNT binds to IFNARs on the endometrial luminal epithelium and superficial glandular epithelium to inhibit transcription of the ESRI gene through a signalling pathway involving IFN regulatory factor (IRF) 2 . These antiluteolytic actions of IFNT on the ESR1 gene prevent ESRI expression and, therefore, the ability of oestrogen to induce expression of OXTR required for pulsatile release of luteolytic PGF (Spencer et al., 2007).

There has been much interest in determining the differences in global transcriptome profiles in embryos derived following natural mating or artificial insemination compared to those produced using assisted reproductive technologies (ART), such as in vitro embryo production or cloning. It is now widely accepted that ART derived embryos have significantly altered gene expression patterns compared to their in vivo derived counterparts (Clemente et al., 2011; Gad et $a l .$, 2012) What is most striking, is that these embryos elicit diverging responses from their recipient maternal endometrium, even though IFNT production levels was found to be similar in these pregnancies (reviewed by Sandra et al., 2015), suggesting that other pathways than IFNT-mediated, are involved in recognition of pregnancy. Comparing endometrial transcriptomes of cows that were recipients of in vivo, IVF-derived or SCNT -embryos revealed distinct patterns of gene expression among the three groups (Bauersachs et al., 2009; Mansouri-Attia et al., 2009b). Moreover, studies show that the supply of numerous amino acids and derivatives was significantly lower in the endometrium of SCNT conceptus-carrying females (Groebner et al., 2011b; Dorniak et al., 2013a).

It is likely that the class I major histocompatibility complex $(M H C-I)$ also plays a role in embryo maternal interaction and modulation of the maternal immune response. The $M H C$, termed the bovine leukocyte antigen (BoLA) in cattle and the human leukocyte antigen (Davies et al., 2006) in humans, encodes a collection of immune and nonimmune related molecules (see Kelley et al., 2005, for review). The class I region of the $M H C$ includes the classical, or class $I a$ genes, the non-classical $(N C)$, class $\mathrm{Ib}$, genes and a number of pseudogenes. Although not directly homologous, classical class I genes have common characteristics across all species, such as high levels of polymorphism and high expression levels; their main function is to discriminate between self and non-self by presenting antigenic peptides to cytotoxic $\mathrm{T}$ lymphocytes, thus eliciting an immune response. Nonclassical class I genes are generally non-polymorphic, have lower expression levels and varied functions (Hughes et al.,1999; Ellis, 2004). Currently there are circa 90 full length class I cDNA sequences validated and listed in the bovine $M H C$ database (http://www.ebi.ac.uk/ipd/ mhc/bola). There are six or more classical $B o L A$ class I genes, expressed in a number of different combinations, such that no more than three are expressed on a haplotype (Ellis et al., 1999; Birch et al., 2008). The existence and genomic location on chromosome 23 , of five bovine $M H C-I b$ genes (named NC1-NC5), is recorded on the database. Their expression has been demonstrated in early cleavage stage bovine embryos (Doyle et al., 2009) binucleate cells (Bainbridge et al., 2001) and in first and second trimester and term trophoblast tissues (Davies et al., 2006). In general, the classical class I genes are found to be down-regulated or modified in the trophoblast cell populations in many mammalian species (for review, see Ellis et al., 2004). MHC-I mRNA expression by bovine embryos is both transcript and embryo stage-specific (Doyle et al., 2009) and can be regulated by a number of cytokines including IFNG, IL-4, and LIF (O'Gorman et al., 2010; Al Naib et al., 2011). Humans express three classical class I genes (HLA-A, -B and -C), and a number of non-classical genes, including HLA-G. HLA-G is expressed by human trophoblast (Ellis et al., 1999), which exists in both membrane-bound and soluble (secreted) alternatively spliced forms. A literature survey on the role of soluble HLA-G (sHLA-G) reported that SHLA-G secreted by early embryos may be necessary for implantation and could represent a good non-invasive marker for pregnancy rate following IVF (Fuzzi et al., 2002; Rizzo et al., 2007). However, the association between sHLA-G concentration and implantation success is not robust (Tabiasco et al., 2009).

We have investigated the mRNA expression profiles of bovine embryos as different stages of pre and peri -implantation development. Embryos were recovered from slaughtered pregnant beef-cross heifers at days 16, 17, 20, 24 and 34 post AI. The relative abundance of trophectodermal NC-MHC-I (BoLA-NC1, $N C 2, N C 3 \& N C 4)$ mRNA expression was analysed using quantitative real time PCR. mRNA expression of $N C B O L A$ sequences was detected at all stages investigated, with expression increasing linearly with embryo development (Reddy et al., 2011). In human, successful trophoblast invasion appears to depend upon the appropriate combination of fetal HLA-C expression by trophoblast and killer cell immunoglobulin-like receptors (Rouas-Freiss et al., 1997) by maternal uterine natural killer (NK) cells, moreover, inappropriate combinations could lead to poor placentation as seen in pre-eclampsia (Hiby et al., 2004). It appears that extravillous human fetal trophoblast cell HLA-G expression may also potentiate maternal immuno-tolerance through modulation of CD4+ T, CD8+ T and NK -cell activity (Rouas-Freiss et al., 1997; Bainbridge et al., 2000; Fournel et al., 2000; Mansouri-Attia et al., 2012; Tilburgs et al., 2015). In general, MHC class I or class I-like ligands bind to KIR and Ly-49 multigene family members. The KIRs are expressed by NK cells and subsets of T cells (Vilches and Parham, 2002); whereas leukocyte immunoglobulin-like receptors (LILR) are expressed by several types of leukocytes (Long, 1999). Binding of MHC-I ligands either inhibits or activates their effector functions. In cattle, inhibitory (KIR2DL or 
KIR3DL) and activating (KIR2DS and KIR3DS) members have been identified (Storset et al., 2003). Non-classical BoLA are produced in both nonsoluble and soluble forms, so it has been speculated that the soluble BoLA also bind LILR receptors on leukocytes in cows, which could inhibit the leukocyte (RapaczLeonard et al., 2014). However, to date, their interaction with trophoblast MHC-I ligands has not been detailed.

\section{Maternal immune cell response to pregnancy}

Although studies on the involvement of the maternal immune system in the establishment of pregnancy in cattle are few in number, particularly, for early pregnancy, monocyte (Mo), macrophages $\mathrm{M} \varnothing$ and dendritic cells (DCs) appear to be the key actors during the implantation period (Fair, 2015). Macrophage recruitment to the pregnant endometrium has been described for a wide range of mammalian species, including the mouse (Fest et al., 2007), human (Mincheva-Nilsson et al., 1994, McIntire et al., 2008), sheep and cattle (Tekin and Hansen, 2004; Oliveira and Hansen, 2009; Oliveira et al., 2010; Mansouri-Attia et al., 2012). Some of the roles associated with macrophages at this time include clearing cellular debris and regulating apoptosis (Straszewski-Chavez et al., 2005), and regulation of placental lactogen concentrations at the fetal-maternal interface (Kzhyshkowska et al., 2008). However, these roles may be more important for mouse and human, where implantation is quite invasive. An additional role, which may be more relevant to ruminant species, is regulating the activation of anti-conceptus immune responses (Oliveira et al., 2010) in response to IFNT stimulation and antigenicity of the conceptus due to paternal antigen and classical MHC protein expression (Doyle et al., 2009). In cattle, using immunofluorescent labeling of immune cell markers, we observed an initial expansion of Mo, MØs (CD14+-cells), and DC (CD172a$\mathrm{CD} 11 \mathrm{c}+$ ) populations in the endometrial stroma on day 13 of pregnancy (Mansouri-Attia et al., 2012). At the same time there was a decline in the number of CD11b positive cells; the loss of $\mathrm{CD} 1 \mathrm{lb}$ expression is characteristic of monocytes acquiring a stationary phenotype (Mansouri-Attia et al., 2012). Which supports their accumulation in the endometrial stroma in response to the embryo. Similarly, a human and mouse specific role of Dendritic cells is involvement in decidua formation (Blois et al., 2007; Plaks et al., 2008). Immunofluorescent labeling of CD172a and CD11c in bovine endometrium sections, revealed a large population of immature cells within the endometrial DC population during early pregnancy (Mansouri-Attia et al., 2012). Immature DC's have been associated with the initiation and maintenance of peripheral tolerance (Dietl et al., 2006) and their presence has been positively associated with the establishment of healthy pregnancies in women (Tirado-Gonzalez et al., 2010). The expansion of these populations in the maternal endometrium is likely to be induced by IFNT.

The maternal immune response to pregnancy in humans, has long been described as a Th1/Th2 dichotomy with an imbalance toward a Th2 type immune response (Wegmann, 1988; Raghupathy, 1997). However, with more in depth transcriptomic and proteomic profiling, this view has been expanded, to take in to account the reported endometrial expression of Th1-type cytokines during implantation and proposed associated requirements for inflammatory signaling during the establishment of pregnancy (Lin et al., 1993; Chaouat, 2007). Using fluorescent labeling of lymphocyte subset markers on endometrial sections, we identified CD4+, CD8+, gamma delta $\mathrm{T}$ and FoxP3+ lymphocyte populations in both pregnant and cyclic cattle from day 5 to 16 of pregnancy/oestrous cycle. The population sizes did not appear to be temporally regulated during the oestrous cycle, or by the presence of an embryo (Oliveira et al., 2013). Although the population size did not alter, the gene expression profile of these cells was temporally modified; inflammatory/Th1 immune factors IFNA, $L I F, I L 1 B$, $I L 8$, and $I L 12 A$ were down regulated during the luteal phase of the oestrus cycle, while Th2 factors $L I F$ and IL10 were upregulated. Our findings suggested that the inflammatory status of T-lymphocytes is modulated during the oestrous cycle, taken together with the similar transcriptome profiles of cyclic and pregnant endometrial tissue, it would appear that the default mechanism in the uterus is to prepare for, and expect, pregnancy (Forde et al., 2011). In contrast to our findings, Correia-Álvarez et al. (2015) reported reduced numbers of CD45-positive leukocytes in the endometrium three days after transfer of in vitro produced bovine day 8 blastocysts to the uterus of heifers, compared to those with sham transfers. Similarly, Groebner et al., 2011a reported fewer CD45positive leukocytes in the zona basalis of pregnant animals on day 18 of pregnancy, simultaneous with an increase in transcripts and elevated enzymatic activity of the tryptophan (Trp) -degrading enzyme indoleamine 2, 3 dioxygenase 1 (IDO). The Authors proposed that the elevated enzyme activity resulted in local Trp ablation, which lead to the reduced the number of leucocytes in the zona basalis of pregnant animals on day 18. However, neither group identified the specific leukocyte subset that was regulated in their study. Endometrial $\mathrm{TGFb} 2$ expression is also down regulated during the ovine and bovine implantation period, but appears to increase specifically in the placentome at this time (Mansouri-Attia et al., 2012). Several roles have been proposed for TGFb2 during placentation: 1) chemoattractant for Mo recruitment to the placentation foci; 2) regulator of trophoblast invasion and 3) regulation of Mo inflammatory status (Wahl et al., 1987; Graham and Lala, 1991).

The final lymphocyte to address is the NK cell, which is an essential player in the establishment of pregnancy in mouse and human. Using immunofluorsecent labeling of CD335+ cells, we found these cells to be surprisingly elusive in bovine endometrial tissue, in cyclic animals and particularly during the early stages of pregnancy (Oliveira et al., 2013). There is evidence from an vitro study suggesting that uterine NK cell expansion could be restricted by 
IFNT (Skopets et al., 1992). Given that in mouse and human, uterine NK cells are critically involved in local vascular remodeling and regulation of trophoblast invasion during implantation (Mor et al., 2011), the restricted NK expansion might be a contributory mechanism by which non-invasive implantation develops in cattle, see review by Bazer et al. (2009).

\section{Peripheral response of the maternal immune system to early pregnancy}

In addition to the local uterine immune response, extra-uterine tissues, including peripheral blood cells (PBL) and the corpus luteum, respond to conceptus secretions (Sandra et al., 2015). The systemic effect of the conceptus has also been investigated with regard to IFNT and the expression of ISG in peripheral blood leucocytes (PBL; Oliveira and Hansen, 2008) and (Ott and Gifford, 2010). As observed in the endometrium, gene expression of ISGs $(M X 1, M X 2$, $O A S 1, I S G 15$ ) is induced in bovine PBLs (Green et al., 2010; Pugliesi et al., 2014) by day 18. These suggest that PBL ISG expression could be evaluated to determine cow pregnancy status (Forde and Lonergan, 2012), or to characterize the post insemination PBL profile of cows that maintain their pregnancies or those that ultimately re-cycle.

\section{Summary}

The role of embryo derived IFNT and the importance of maternal macrophage and dendritic cells in the establishment of pregnancy in cattle is widely understood. Further support for basic research in the area of bovine reproductive immunology is essential to generate new knowledge of the mechanisms involved in maternal - embryo immunological cross-talk. This information will lead to a better understanding of the optimal maternal immunophenotype to support early embryo development and implantation and facilitate the optimization of transition and post-partum -cow management to ensure this phenotype is achieved prior to breeding.

\section{References}

Al Naib A, Mamo S, O'Gorman GM, Lonergan P, Swales A, Fair T. 2011. Regulation of non-classical major histocompatability complex class I mRNA expression in bovine embryos. J Reprod Immunol, 91:31-40.

Bainbridge DR, Ellis SA, Sargent IL. 2000. HLA-G suppresses proliferation of CD4(+) T-lymphocytes. $J$ Reprod Immunol, 48:17-26.

Bainbridge DR, Sargent I, Ellis S. 2001. Increased expression of major histocompatibility complex (MHC) class I transplantation antigens in bovine trophoblast cells before fusion with maternal cells. Reproduction, 122:907-913.

Bauersachs S, Ulbrich SE, Gross K, Schmidt SE, Meyer HH, Wenigerkind $H$, Vermehren $M$,
Sinowatz F, Blum H, Wolf E. 2006. Embryo-induced transcriptome changes in bovine endometrium reveal species-specific and common molecular markers of uterine receptivity. Reproduction, 132:319-331.

Bauersachs S, Ulbrich SE, Zakhartchenko V, Minten M, Reichenbach M, Reichenbach HD, Blum H, Spencer TE, Wolf E. 2009. The endometrium responds differently to cloned versus fertilized embryos. Proc Natl Acad Sci USA, 106:5681-5686.

Bauersachs S, Ulbrich SE, Reichenbach HD, Reichenbach M, Buttner M, Meyer HH, Spencer TE, Minten M, Sax G, Winter G, Wolf E. 2012. Comparison of the effects of early pregnancy with human interferon, alpha 2 (IFNA2), on gene expression in bovine endometrium. Biol Reprod, 86:46.

Bazer FW. 1975. Uterine protein secretions: relationship to development of the conceptus. J Anim Sci, 41:1376-1382.

Bazer FW, Spencer TE, Johnson GA. 2009. Interferons and uterine receptivity. Semin Reprod Med, 27:90-102.

Birch, J, Codner G, Guzman E, Ellis SA. 2008. Genomic location and characterisation of nonclassical MHC class I genes in cattle. Immunogenetics, 60:267273.

Blois SM, Kammerer U, Alba Soto C, Tometten MC, Shaikly V, Barrientos G, Jurd R, Rukavina D, Thomson AW, Klapp BF, Fernández N, Arck PC. 2007. Dendritic cells: key to fetal tolerance? Biol Reprod, 77:590-598.

Bromfield JJ. 2014. Seminal fluid and reproduction: much more than previously thought. $J$ Assist Reprod Genet, 31:627-36.

Bromfield JJ, Schjenken JE, Chin PY, Care AS, Jasper MJ, Robertson SA. 2014. Maternal tract factors contribute to paternal seminal fluid impact on metabolic phenotype in offspring. Proc Natl Acad Sci USA, 111:2200-2205.

Brooks K, Burns G, Spencer TE. 2014. Conceptus elongation in ruminants: roles of progesterone, prostaglandin, interferon tau and cortisol. J Anim Sci Biotechnol, 5:1-12.

Chaouat G. 2007. The Th1/Th2 paradigm: still important in pregnancy? Semin Immunopathol, 29:95-113.

Choi Y, Johnson GA, Spencer TE, Bazer FW. 2003. Pregnancy and interferon tau regulate major histocompatibility complex class I and Beta2microglobulin expression in the ovine uterus. Biol Reprod, 68:1703-1710.

Clemente M, Lopez-Vidriero I, O'Gaora P, Mehta JP, Forde N, Gutierrez-Adan A, Lonergan P, Rizos D. 2011. Transcriptome changes at the initiation of elongation in the bovine conceptus. Biol Reprod, 85:285-295.

Correia-Álvarez E, Gómez E, Martín D, Carrocera S, Pérez S, Peynot N, Giraud-Delville C, Caamaño JN, Balseiro A, Sandra O, Duranthon V,Muñoz M. 2015. Early embryonic and endometrial regulation of tumor necrosis factor and tumor necrosis factor receptor 2 in the cattle uterus. Theriogenology, 83:1028-1037.

Davies CJ, Eldridge JA, Fisher PJ, Schlafer DH. 2006. evidence for expression of both classical and non- 
classical major histocompatibility complex class I genes in bovine trophoblast cells. Am J Reprod Immunol, 55:188-200.

Dietl J, Hönig A, Kämmerer U, Rieger L. 2006. Natural killer cells and dendritic cells at the human fetomaternal interface: an effective cooperation? Placenta, 27:341-347.

Ding YB, Chen GY, Xia JG, Zang XW, Yang HY, Yang L. 2003. Association of VCAM-1 over expression with oncogenesis, tumor angiogenesis and metastasis of gastric carcinoma. World J Gastroenterol, 9:1409-1414. Dorniak P, Bazer FW, Wu G, Spencer TE. 2012. Conceptus-derived prostaglandins regulate endometrial function in sheep. Biol Reprod, 87:1-7.

Dorniak P, Bazer FW, Spencer TE. 2013a. Physiology and endocrinology symposium: biological role of interferon tau in endometrial function and conceptus elongation. J Anim Sci, 91:1627-1638.

Dorniak P, Welsh TH, Bazer FW, Spencer TE. 2013b. Cortisol and interferon tau regulation of endometrial function and conceptus development in female sheep. Endocrinology, 154:931-941.

Doyle J, Ellis SA, O'Gorman GM, Aparicio Donoso IM, Lonergan P, Fair T. 2009. Classical and nonclassical major histocompatibility complex class I gene expression in in vitro derived bovine embryos. $J$ Reprod Immunol, 82:48-56.

Ellis SA, Holmes EC, Staines KA, Smith KB, Stear MJ, McKeever DJ, MacHugh ND, Morrison WI. 1999. Variation in the number of expressed MHC genes in different cattle class I haplotypes. Immunogenetics, 50:319-328.

Ellis SA. 2004. Review: immune status: normal expression of MHC class I in the placenta and what is expected in clones. Cloning Stem Cells, 6:121-125.

Fair T. 2015. The contribution of the maternal immune system to the establishment of pregnancy in cattle. Front Immunol, 28:6-7.

Fest S, Aldo PB, Abrahams VM, Visintin I, Alvero A, Chen R, Chavez SL, Romero R, Mor G. 2007. Trophoblast-macrophage interactions:

a regulatory network for the protection of pregnancy. Am J Reprod Immunol, 57:55-66.

Forde N, Carter F, Spencer TE, Bazer FW, Sandra O, Mansouri-Attia N, Okumu LA, McGettigan PA, Mehta JP, McBride R, O'Gaora P, Roche JF, Lonergan P. 2011. Conceptus-induced changes in the endometrial transcriptome: how soon does the cow know she is pregnant? Biol Reprod, 85:144-156.

Forde N, Lonergan P. 2012. Transcriptomic analysis of the bovine endometrium: what is required to establish uterine receptivity to implantation in cattle? J Reprod Dev, 58:189-195.

Fournel S, Aguerre-Girr M, Huc X, Lenfant F, Alam A, Toubert A, Bensussan A, Le Bouteiller P. 2000. Cutting edge: soluble HLA-G1 triggers CD95/CD95 ligand-mediated apoptosis in activated CD8+ cells by nnteracting with CD8. J Immunol, 164:6100-6104.

Fuzzi B, Rizzo R, Criscuoli L, Noci I, Melchiorri L, Scarselli B, Bencini E, Menicucci A, Baricordi OR. 2002. HLA-G Expression in early embryos is a fundamental prerequisite for the obtainment of pregnancy. Eur J Immunol, 32:311-315.

Gad A, Hoelker M, Besenfelder U, Havlicek V, Cinar U, Rings F, Held E, Dufort I, Sirard M-A, Schellander K, Tesfaye D. 2012. Molecular mechanisms and pathways involved in bovine embryonic genome activation and their regulation by alternative in vivo and in vitro culture conditions. Biol Reprod, 87:100.

Graham CH, Lala PK. 1991. Mechanism of control of trophoblast invasion in situ. J Cell Physiol, 148:228234.

Green JC, Okamura CS, Poock SE, Lucy MC. 2010. Measurement of interferon-tau (IFN-tau) stimulated gene expression in blood leukocytes for pregnancy diagnosis within 18-20d after insemination in dairy cattle. Anim Reprod Sci, 121:24-33.

Groebner AE, Schulke K, Schefold JC, Fusch G, Sinowatz F, Reichenbach HD, Wolf E, Meyer HHD, Ulbrich SE. 2011a. Immunological mechanisms to establish embryo tolerance in early bovine pregnancy. Reprod Fertil Dev, 23:619-632.

Groebner AE, Zakhartchenko V, Bauersachs S, Rubio-Aliaga I, Daniel H, Buttner M, Reichenbach HD, Meyer HH, Wolf E, Ulbrich SE. 2011b. Reduced amino acids in the bovine uterine lumen of cloned versus in vitro fertilized pregnancies prior to implantation. Cell Reprogram, 13:403-410.

Gurtner GC, Davis V, Li H, Mccoy MJ, Sharpe A, Cybulsky MI. 1995. Targeted disruption of the murine VCAM1 gene: essential role of VCAM-1 in chorioallantoic fusion and placentation. Genes Dev, 9:114.

Hansen TR, Austin KJ, Johnson GA. 1997. Transient ubiquitin cross-reactive protein gene expression in the bovine endometrium. Endocrinology, 138:5079-5082.

Hansen TR, Austin KJ, Perry DJ, Pru JK, Teixeira MG, Johnson GA. 1999. Mechanism of action of interferon-tau in the uterus during early pregnancy. $J$ Reprod Fertil, 54:329-339.

Hiby SE, Walker JJ, O'Shaughnessy KM, Redman CWG, Carrington M, Trowsdale J, Moffett A. 2004. Combinations of maternal KIR and fetal HLA-C genes influence the risk of preeclampsia and reproductive success. J Exp Med, 200:957-965.

Hicks BA, Etter SJ, Carnahan KG, Joyce MM, Assiri AA, Carling SJ, Kodali K, Johnson GA, Hansen TR, Mirando MA, Woods GL, Vanderwall DK, Ott TL. 2003. Expression of the uterine Mx protein in cyclic and pregnant cows, gilts, and mares. $J$ Anim Sci, 81:1552-61.

Hughes AL, Yeager M, Ten Elshof AE, Chorney MJ. 1999. New taxonomy of mammalian MHC class I molecules. Immunol Today, 20:22-26.

Imakawa K, Tamura K, Lee RS, Ji Y, Kogo H, Sakai S, Christenson RK. 2002. Temporal expression of type $i$ interferon receptor in the peri-implantation ovine extra-embryonic membranes: demonstration that human ifnalpha can bind to this receptor. Endocr J, 49:195205.

Imakawa K, Imai M, Sakai A, Suzuki M, Nagaoka K, Sakai S, Lee SR, Chang KT, Echternkamp SE, Christenson RK. 2006. Regulation of conceptus 
adhesion by endometrial CXC chemokines during the implantation period in sheep. Mol Reprod Dev, 73:850858.

Johnson GA, Spencer TE, Hansen TR, Austin KJ, Burghardt RC, Bazer FW. 1999. Expression of the interferon tau inducible ubiquitin cross-reactive protein in the ovine uterus. Biol Reprod, 61:312-318

Johnson GA, Spencer TE, Burghardt RC, Joyce MM, Bazer FW. 2000. Interferon-tau and progesterone regulate ubiquitin cross-reactive protein expression in the ovine uterus. Biol Reprod, 62:622-627.

Kelley J, Walter L, Trowsdale J. 2005. Comparative genomics of major histocompatibility complexes. Immunogenetics, 56:683-695.

Klein C, Bauersachs S, Ulbrich S E, Einspanier R, Meyer HH, Schmidt SE, Reichenbach HD, Vermehren M, Sinowatz F, Blum H, Wolf E. 2006. Monozygotic twin model reveals novel embryo-induced transcriptome changes of bovine endometrium in the preattachment period. Biol Reprod, 74:253-264.

Kzhyshkowska J, Gratchev A, Schmuttermaier C, Brundiers H, Krusell L, Mamidi S, Zhang J, Workman G, Sage EH, Anderle C, Sedlmayr P, Goerdt S. 2008. Alternatively activated macrophages regulate extracellular levels of the hormone placental lactogen via receptor-mediated uptake and transcytosis. J Immunol, 180:3028-3037.

Li J, Roberts RM. 1994. Interferon-tau and interferonalpha interact with the same receptors in bovine endometrium. Use of a readily iodinatable form of recombinant interferon-tau for binding studies. $J$ Biol Chem, 269:13544-13550.

Lima FS, Risco CA, Thatcher MJ, Benzaquen ME, Archbald LF, Santos JE, Thatcher WW. 2009. Comparison of reproductive performance in lactating dairy cows bred by natural service or timed artificial insemination. J Dairy Sci, 92:5456-5466.

Lin H, Mosmann TR, Guilbert L, Tuntipopipat S, Wegmann TG. 1993. Synthesis of T helper 2-type cytokines at the maternal-fetal interface. J Immunol, 151:4562-4573.

Lonergan P, Forde N. 2014. Maternal-embryo interaction leading up to the initiation of implantation of pregnancy in cattle. Animal, 8:64-69.

Long EO. 1999. Regulation of immune responses through inhibitory receptors. Annu Rev Immunol, 17:875-904

MacIntyre DM, Lim HC, Ryan K, Kimmins S, Small JA, Maclaren LA. 2002. Implantation-associated changes in bovine uterine expression of integrins and extracellular matrix. Biol Reprod, 66:1430-1436.

Mamo S, Mehta JP, Mcgettigan P, Fair T, Spencer TE, Bazer FW, Lonergan P. 2011. RNA sequencing reveals novel gene clusters in bovine conceptuses associated with maternal recognition of pregnancy and implantation. Biol Reprod, 85:1143-51.

Mansouri-Attia N, Aubert J, Reinaud P, GiraudDelville C, Taghouti G, Galio L, Everts RE, Degrelle S, Richard C, Hue I, Yang X, Tian XC, Lewin HA, Renard JP, Sandra O. 2009a. Gene expression profiles of bovine caruncular and intercaruncular endometrium at implantation. Physiol Genomics, 39:14-27.
Mansouri-Attia N, Sandra O, Aubert J, Degrelle S, Everts RE, Giraud-Delville C, Heyman Y, Galio L, Hue I, Yang X, Tian XC, Lewin HA, Renard JP. 2009b. Endometrium as an early sensor of in vitro embryo manipulation technologies. Proc Natl Acad Sci USA, 106:5687-5692.

Mansouri-Attia N, Oliveira LJ, Forde N, Fahey AG, Browne JA, Roche JF, Sandra O, Reinaud P, Lonergan P, Fair T. 2012. Pivotal role for monocytes/macrophages and dendritic cells in maternal immune response to the developing embryo in cattle. Biol Reprod, 87:123.

May MJ, Entwistle G, Humphries MJ, Ager A. 1993. VCAM-1 is a CS1 peptide-inhibitable adhesion molecule expressed by lymph node high endothelium. $J$ Cell Sci, 106(pt. 1):109-119.

McIntire RH, Ganacias KG, Hunt JS. 2008. Programming of human monocytes by the uteroplacental environment. Reprod Sci, 15:437-447.

Mincheva-Nilsson L, Baranov V, Yeung MM, Hammarstrom S, Hammarstrom ML. 1994. Immunomorphologic studies of human deciduaassociated lymphoid cells in normal early pregnancy. $J$ Immunol, 152:2020-2032.

Moldenhauer LM, Diener KR, Thring DM, Brown MP, Hayball JD, Robertson SA. 2009. Crosspresentation of male seminal fluid antigens elicits $\mathrm{T}$ cell activation to initiate the female immune response to pregnancy. J Immunol, 182:8080-8093.

Mor G, Cardenas I, Abrahams V, Guller S. 2011. Inflammation and pregnancy: the role of the immune system at the implantation site. Ann N Y Acad Sci, 1221:80-87.

Nagaoka K, Nojima H, Watanabe F, Chang KT, Christenson RK, Saka S, Imakawa K. 2003a. Regulation of blastocyst migration, apposition, and initial adhesion by a chemokine, interferon gammainducible protein $10 \mathrm{kDa}$ (IP-10), during early gestation. J Biol Chem, 278:29048-56.

Nagaoka K, Sakai A, Nojima H, Suda Y, Yokomizo Y, Imakawa K, Sakai S, Christenson RK. 2003b. A chemokine, interferon (IFN)-gamma-inducible protein $10 \mathrm{kDa}$, is stimulated by ifn-tau and recruits immune cells in the ovine endometrium. Biol Reprod, 68:14131421.

O'Gorman GM, Naib AA, Ellis SA, Mamo S, O'Doherty AM, Lonergan P, Fair T. 2010. Regulation of a bovine nonclassical major histocompatibility complex class I gene promoter. Biol Reprod, 83:296306.

Odhiambo JF, Poole DH, Hughes L, Dejarnette JM, Inskeep EK, Dailey RA. 2009. Pregnancy outcome in dairy and beef cattle after artificial insemination and treatment with seminal plasma or transforming growth factor beta-1. Theriogenology, 72:566-71.

Oliveira LJ, Hansen PJ. 2008. Deviations in populations of peripheral blood mononuclear cells and endometrial macrophages in the cow during pregnancy. Reproduction, 136:481-490.

Oliveira LJ, Hansen PJ. 2009. Phenotypic characterization of macrophages in the endometrium of the pregnant cow. Am J Reprod Immunol, 62:418-426. 
Oliveira LJ, McClellan S, Hansen PJ. 2010. Differentiation of the endometrial macrophage during pregnancy in the cow. Plos One, 5:E13213.

Oliveira LJ, Mansouri-Attia N, Fahey AG, Browne J, Forde N, Roche JF, Lonergan P, Fair T. 2013. Characterization of the $\mathrm{Th}$ profile of the bovine endometrium during the oestrous cycle and early pregnancy. Plos One, 8:e75571.

Osborn L, Hession C, Tizard R, Vassallo C, Luhowskyj S, Chi-Rosso G, Lobb R. 1989. Direct expression cloning of vascular cell adhesion molecule 1 , a cytokine-induced endothelial protein that binds to lymphocytes. Cell, 59:1203-11.

Ott TL, Yin J, Wiley AA, Kim HT, Gerami-Naini B, Spencer TE, Bartol FF, Burghardt RC, Bazer FW. 1998. Effects of the estrous cycle and early pregnancy on uterine expression of $\mathrm{mx}$ protein in sheep (Ovis aries). Biol Reprod, 59:784-794.

Ott TL, Gifford CA. 2010. Effects of early conceptus signals on circulating immune cells: lessons from domestic ruminants. Am J Reproductive Immunol, 64:245-254

Pfarrer C, Hirsch P, Guillomot M, Leiser R. 2003. Interaction of integrin receptors with extracellular matrix is involved in trophoblast giant cell migration in bovine placentomes. Placenta, 24:588-597.

Pfarrer CD. 2006. Characterization of the bovine placenta by cytoskeleton, integrin receptors, and extracellular matrix. Methods Mol Med, 121:323-335.

Plaks V, Birnberg T, Berkutzki T, Sela S, Benyashar A, Kalchenko V, Mor G, Keshet E, Dekel N, Neeman M, Jung S. 2008. Uterine DCs are crucial for decidua formation during embryo implantation in mice. $J$ Clin Invest, 118:3954-65.

Pugliesi G, Miagawa BT, Paiva YN, França MR, Silva LA, Binelli M. 2014. Conceptus-induced changes in the gene expression of blood immune cells and the ultrasound-accessed luteal function in beef cattle: how early can we detect pregnancy? Biol Reprod 91:95.

Raghupathy R. 1997. Th1-type immunity is incompatible with successful pregnancy. Immunol Today, 18:478-482.

Randi F, Fernandez-Fuertes B, McDonald M, Forde N, Kelly AK, Bastos Amorin H, Muniz de Lima E, Morotti F, Seneda MM, Lonergan P. 2015. Asynchronous embryo transfer as a tool to understand embryo-uterine interaction in cattle: is a large conceptus a good thing? Reprod Fertil Dev. doi: 10.1071/RD15195.

Rapacz-Leonard A, Dąbrowska M, Janowski T. 2014. Major histocompatibility complex I mediates immunological tolerance of the trophoblast during pregnancy and may mediate rejection during parturition. Mediators Inflamm, 2014:579279.

Reddy E, Mansouri-Attia N, Hue N, Coady M, Fitzpatrick E, Fahey A, Lonergan P, Fair T. 2011. Characterisation of non-classical MHC-I gene expression in bovine peri-implantation conceptii. $J$ Reprod Immunol, 90:164:183.

Rizzo R, Melchiorri L, Stignani M, Baricordi OR. 2007. HLA-G expression is a fundamental prerequisite to pregnancy. Hum Immunol, 68:244-250.
Roberts RM, Cross JC, Leaman DW. 1992. Interferons as hormones of pregnancy. Endocr Rev, 13:432-452.

Robertson SA, Mau VJ, Tremellen KP, Seamark RF. 1996. Role of high molecular weight seminal vesicle proteins in eliciting the uterine inflammatory response to semen in mice. J Reprod Fertil, 107:265-77.

Robertson SA, O'Connel, AC, Hudson SN, Seamark RF. 2000. granulocyte-macrophage colony-stimulating factor (GM-CSF) targets myeloid leukocytes in the uterus during the post-mating inflammatory response in mice. J Reprod Immunol, 46:131-54.

Robertson SA. 2005. Seminal plasma and male factor signalling in the female reproductive tract. Cell Tissue Res, 322:43-52.

Robertson SA. 2007. Seminal fluid signaling in the female reproductive tract: lessons from rodents and pigs. J Anim Sci, 85:E36-44.

Robinson RS, Fray MD, Wathes DC, Lamming GE, Mann GE. 2006. In vivo expression of interferon tau mRNA by the embryonic trophoblast and uterine concentrations of interferon tau protein during early pregnancy in the cow. Mol Reprod Dev, 73:470-474.

Rosenfeld CS, Han CS, Alexenko AP, Spencer TE, Roberts RM. 2002. Expression of interferon receptor subunits, IFNAR1 and IFNAR2, in the ovine uterus. Biol Reprod, 67:847-853.

Rouas-Freiss N, Marchal RE, Kirszenbaum M, Dausset J, Carosella ED. 1997. The alpha1 domain of HLA-G1 And HLA-G2 inhibits cytotoxicity induced by natural killer cells: is HLA-G the public ligand for natural killer cell inhibitory receptors? Proc Natl Acad Sci USA, 94:5249-5254.

Sandra O, Constant F, Vitorino Carvalho A, Eozenou C, Valour D, Mauffre V, Hue I, Charpigny G. 2015. Maternal organism and embryo biosensoring: insights from ruminants. J Reprod Immunol, 108:105113.

Shirasuna K, Nitta A, Sineenard J, Shimizu T, Bollwein H, Miyamoto A. 2012. Vascular and immune regulation of corpus luteum development, maintenance, and regression in the cow. Domest Anim Endocrinol, 43:198-211.

Skopets B, Li J, Thatcher WW, Roberts RM, Hansen PJ. 1992. Inhibition of lymphocyte proliferation by bovine trophoblast protein-1 (type I trophoblast interferon) and bovine interferon-alpha I1. Vet Immunol Immunopathol, 34:81-96.

Song G, Bazer FW, Spencer TE. 2007. Pregnancy and interferon tau regulate RSAD2 and ifih1 expression in the ovine uterus. Reproduction, 133:285-295.

Spencer TE, Johnson GA, Bazer FW, Burghardt RC, Palmarini M. 2007. Pregnancy recognition and conceptus implantation in domestic ruminants: roles of progesterone, interferons and endogenous retroviruses. Reprod Fertil Dev, 19:65:78.

Spencer TE, Sandra O, Wolf E. 2008. Genes involved in conceptus-endometrial interactions in ruminants: insights from reductionism and thoughts on holistic approaches. Reproduction, 135:165-179.

Spencer TE, Forde N, Dorniak P, Hansen TR, Romero JJ, Lonergan P. 2013. Conceptus-derived 
prostaglandins regulate gene expression in the endometrium prior to pregnancy recognition in ruminants. Reproduction, 146:377-387.

Storset AK, Slettedal IÖ, Williams JL, Law A, Dissen E. 2003. Natural killer cell receptors in cattle: a bovine killer cell immunoglobulin-like receptor multigene family contains members with divergent signaling motifs. Eur J Immunol, 33:980-990.

Straszewski-Chavez SL, Abrahams VM, Mor G. 2005. The role of apoptosis in the regulation of trophoblast survival and differentiation during pregnancy. Endocr Rev, 26:877-897.

Tabiasco J', Perrier d'Hauterive S, Thonon F, Parinaud J, Léandri R, Foidart JM, Chaouat G, Munaut C, Lombroso R, Selva J, Bergère M, Hammoud I, Kozma N, Aguerre-Girr M, Swales AK, Sargent IL, Le Bouteiller P, Lédée N. 2009. Soluble HLA-G in IVF/ICSI embryo culture supernatants does not always predict implantation success: a multicentre study. Reprod Biomed Online, 18:374-381.

Tekin S, Hansen PJ. 2004. Regulation of numbers of macrophages in the endometrium of the sheep by systemic effects of pregnancy, local presence of the conceptus, and progesterone. Am J Reprod Immunol, 51:56-62.

Tilburgs T, Evans JH, Crespo ÂC, Strominger JL.
2015. The HLA-G cycle provides for both NK tolerance and immunity at the maternal-fetal interface. Proc Natl Acad Sci USA, 112:13312-13317.

Tirado-Gonzalez I, Munoz-Fernandez R, Blanco O, Leno-Duran E, Abadia-Molina AC, Olivares EG. 2010. Reduced proportion of decidual DC-SIGN+ cells in human spontaneous abortion. Placenta, 31:10191022.

Vilches C, Parham P. 2002. KIR: diverse, rapidly evolving receptors of innate and adaptive immunity. Annu Rev Immunol, 20:217-251.

Wahl SM, Hunt DA, Wakefield LM, MccartneyFrancis N, Wahl LM, Roberts AB, Sporn, MB. 1987. Transforming growth factor type beta induces monocyte chemotaxis and growth factor production. Proc Natl Acad Sci USA, 84:5788-5792.

Wegmann TG. 1988. Maternal T cells promote placental growth and prevent spontaneous abortion. Immunol Lett, 17:297-302.

Wooding FB, Beckers JF. 1987. Trinucleate cells and the ultrastructural localisation of bovine placental lactogen. Cell Tissue Res, 247:667-673.

Wooding FB. 1992. Current topic: the synepitheliochorial placenta of ruminants: binucleate cell fusions and hormone production. Placenta, 13:101113. 